\title{
Langerhans Cell Histiocytosis of the Clavicle in an Adult: A Case Report and Review of the Literature
}

\author{
Toru Udaka ${ }^{a, d}$ Michiro Susa ${ }^{a, c}$ Kazutaka Kikuta ${ }^{a}$ \\ Kazumasa Nishimoto ${ }^{a}$ Keisuke Horiuchi ${ }^{a}$ Aya Sasaki ${ }^{b}$ \\ Kaori Kameyama ${ }^{b}$ Masaya Nakamura ${ }^{a}$ Morio Matsumoto ${ }^{a}$ \\ Kazuhiro Chiba ${ }^{c}$ Hideo Morioka ${ }^{a}$ \\ ${ }^{a}$ Department of Orthopaedic Surgery and ${ }^{b}$ Division of Surgical Pathology, Keio University \\ School of Medicine, Tokyo, 'Department of Orthopaedic Surgery, National Defense \\ Medical College, Tokorozawa, and ${ }^{\mathrm{d}}$ Department of Orthopaedic Surgery, Tochigi Medical \\ Center, Utsunomiya, Japan
}

\section{Key Words}

Langerhans cell histiocytosis · Clavicle $\cdot$ Adult

\begin{abstract}
Langerhans cell histiocytosis (LCH) usually occurs in children under the age of 10 years with a predilection for the skull, spine, rib and humerus. Solitary LCH occurring in an adult clavicle is uncommon with limited reports to date. The lesion in our patient was curetted with the intent to make a diagnosis, which subsequently lead to the remission of the symptom and the disease. At the final follow-up after 1 year, no local recurrence or metastasis is observed.
\end{abstract}

\section{Introduction}

Langerhans cell histiocytosis (LCH) is a rare histiocytic disorder characterized by abnormal proliferation of functionally immature Langerhans cells. The prevalence of LCH is estimated to be 1-2 cases per 1 million people [1]. It predominantly occurs in the pediatric population, and its clinical presentation is variable. When it occurs in the bone, it has a predilection for the skull, spine, rib and humerus. We present a case of solitary LCH occurring in an adult clavicle, a rare presentation with limited cases reported in published studies.

KARGER 125/s $\begin{aligned} & \text { Michiro Susa } \\ & \text { Department of Orthopaedic Surgery } \\ & \text { National Defense Medical College } \\ & 3-2 \text { Namiki, Tokorozawa, Saitama 359-8513 (Japan) } \\ & \text { E-Mail mitchsusa@gmail.com }\end{aligned}$


Udaka et al.: Langerhans Cell Histiocytosis of the Clavicle in an Adult: A Case Report and Review of the Literature

\section{Case Report}

A 25-year-old female presented with a left shoulder pain that had persisted for 2 months. She had no incidence of trauma or prior medical history. Due to deteriorating pain, she visited a nearby hospital and was diagnosed with bone tumor of the clavicle on radiography. She then was referred to our institute for further treatment. On initial physical examination, the overlying skin was smooth with slight redness. There was hotness with tenderness upon pressure in the area. The range of motion of the left shoulder was limited due to pain. On the plain radiograph, there was a 2-cm osteolytic lesion in the middle third of clavicle with slight periosteal reaction (fig. 1). On MRI, the lesion was depicted as low intensity on T1-WI and high on T2-WI, with the extra-skeletal mass extending to the coracoid process (fig. 2). On positron emission tomography (PET)-CT, the lesion was solitary with a maximum standardized uptake value (SUVmax) of 14.23 (fig. 3). The blood examination results were all in the normal range. Differential diagnosis included malignant lesions such as Ewing sarcoma and plasmacytoma; therefore, open biopsy was performed. On histopathologic examination, the lesion was composed of histiocytic appearing cells with prominent eosinophils. On immunohistochemistry, the lesion was positive for CD1a and S-100, confirming the diagnosis of LCH (fig. 4). One year after biopsy, the lesion is well healed with no local recurrence or distant metastasis.

\section{Discussion}

LCH is an abnormal proliferation of tissue macrophage called Langerhans cells which was previously known as histiocytosis $\mathrm{X}$ that grouped eosinophilic granuloma, HandSchüller-Christian disease and Letterer-Siwe disease. The etiology of this entity is still unknown, with conflicting reports between its neoplastic origin and the possibility of a reactive immune condition. Recent findings of a mutation in BRAF [2] and MAP2K1 [3] have led to the assumption of its neoplastic origin, at least in some subgroups. LCH occurring in an adult is uncommon, since LCH predominantly occurs in children, with approximately $80 \%$ of the disease happening under the age of 15 [4]. Although the majority of LCH occurs as a solitary lesion, it could also present as multiple lesions involving the skin, lymph node, lung, liver and spleen. Wester et al. [5] reported 61 cases of LCH occurring in adults, with only $6 \%$ involving the clavicle. A solitary lesion in the clavicle is extremely rare, and only 12 cases have been reported to date [4-12].

Diagnosis of LCH is sometimes difficult and it is reported to be underdiagnosed especially in the adult population. The most frequent lesion occurring in an adult clavicle is a metastasis of carcinoma, but the radiographic differentiation between metastasis, osteomyelitis and LCH is often difficult. Although most of the malignant tumors occur in the end of the bone, localization is not particularly helpful for a definitive diagnosis. Utilization of PET-CT for LCH has been reported in a number of studies, and efficacy has been shown for overall disease extension and posttreatment assessment. It is superior to bone scintigraphy, where only $35 \%$ of the cases are detected, but it does not lead to a definitive diagnosis [13]. Cortical destruction and soft tissue extension that was observed in our case are rare, and biopsy is mandatory to make a diagnosis. Although uncommon, LCH should be considered in the differential diagnosis of an osteolytic lesion occurring in an adult clavicle.

Treatment consists of surgery, radiation therapy, chemotherapy and combination therapy depending on the localization and spread of the lesion. Surgery is usually sufficient for solitary lesions, where only 2 local recurrences among the 61 cases have been reported for 
Udaka et al.: Langerhans Cell Histiocytosis of the Clavicle in an Adult: A Case Report and Review of the Literature

adult LCH [5]. Several options for surgery have been reported from biopsy alone to curettage with bone grafting. Because some LCH undergo spontaneous regression, it is prudent to limit the invasiveness of the treatment for small lesions. In our case, biopsy was sufficient to achieve resolution of the disease. There has been only one report of a malignant $\mathrm{LCH}$ of the clavicle, and although the lesion is extremely heterogeneous in presentation, local aggressiveness such as pathological fracture warrants cautious follow-up [14].

\section{Conclusion}

We have reported a rare case of solitary LCH occurring in an adult clavicle. Open biopsy for definitive diagnosis of the lesion subsequently led to remission of the lesion. Although uncommon, LCH should be considered in the differential diagnosis of an osteolytic lesion in the clavicle. The rarity of this tumor occurring in an adult clavicle has not enabled prediction of the outcome, therefore additional follow-up is warranted.

\section{Statement of Ethics}

The authors have no ethical conflicts to disclose. Informed consent was obtained from the patient for this case report and any accompanying images.

\section{Disclosure Statement}

The authors have no conflicts of interest to declare.

\section{References}

1 Arceci RJ: The histiocytoses: the fall of the Tower of Babel. Eur J Cancer 1999;35:747-769.

-2 Badalian-Very G, Vergilio JA, Degar BA, MacConaill LE, Brandner B, Calicchio ML, Kuo FC, Ligon AH, Stevenson KE, Kehoe SM, Garraway LA, Hahn WC, Meyerson M, Fleming MD, Rollins BJ: Recurrent BRAF mutations in Langerhans cell histiocytosis. Blood 2010;116:1919-1923.

3 Brown NA, Furtado LV, Betz BL, Kiel MJ, Weigelin HC, Lim MS, Elenitoba-Johnson KS: High prevalence of somatic MAP2K1 mutations in BRAF V600E-negative Langerhans cell histiocytosis. Blood 2014;124:16551658.

4 Weitzman S, Jaffe R: Uncommon histiocytic disorders: the non-Langerhans cell histiocytoses. Pediatr Blood Cancer 2005; 45:256-264.

5 Wester SM, Beabout JW, Unni KK, Dahlin DC: Langerhans' cell granulomatosis (histiocytosis X) of bone in adults. Am J Surg Pathol 1982;6:413-426.

6 Franklin JL, Parker JC, King HA: Nontraumatic clavicle lesions in children. J Pediatr Orthop 1987;7:575-578.

7 Gilbert NF, Deavers MT, Madewell JE, Lewis VO: A 16-year-old girl with pain and swelling in the medial clavicle. Clin Orthop Relat Res 2008;466:3158-3162.

-8 Kapoor S, Tiwari A: Primary tumours and tumorous lesions of clavicle. Int Orthop 2008;32:829-834.

$\checkmark 9$ Parikh SN, Desai VR, Gupta A, Anton CG: Langerhans cell histiocytosis of the clavicle in a 13-year-old boy. Case Rep Orthop 2014;2014:510287.

10 Verbist B, Geusens E, Brys P, Verslegers I, Samson I, Sciot R, Baert AL: Langerhans cell histiocytosis of the clavicle: a case report. Eur Radiol 1998;8:1357-1358.

11 Wang S, Zhang W, Na S, Zhang L, Lang Z: Langerhans cell histiocytosis of the clavicle: a case report and review of the literature. Medicine (Baltimore) 2014;93:e117.

-12 Wilson S, Yerger ES, Neitzschman HR, Walcott JL: Radiology case of the month. Right clavicle lesion. Lytic lesion of the right clavicle. J La State Med Soc 1999;151:69-71.

13 Phillips M, Allen C, Gerson P, McClain K: Comparison of FDG-PET scans to conventional radiography and bone scans in management of Langerhans cell histiocytosis. Pediatr Blood Cancer 2009;52:97-101. 


\section{Case Reports in Oncology}

\begin{tabular}{l|l}
\hline Case Rep Oncol 2015;8:426-431 \\
\hline DOI: 10.1159/000441415 & $\begin{array}{l}\text { ○ 2015 The Author(s). Published by S. Karger AG, Basel } \\
\text { www.karger.com/cro }\end{array}$ \\
\hline
\end{tabular}

Udaka et al.: Langerhans Cell Histiocytosis of the Clavicle in an Adult: A Case Report and Review of the Literature

14 Salam A, Eyres K, Cleary J: Malignant Langerhans' cell histiocytosis of the clavicle: a rare pathological fracture. Br J Clin Pract 1990;44:652-654.
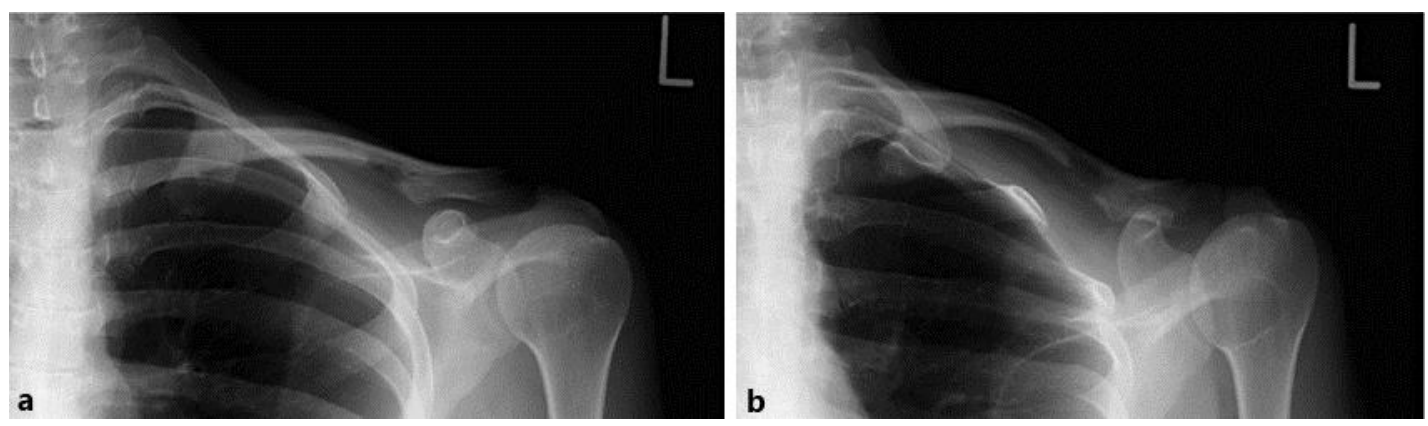

Fig. 1. Radiograph of the left clavicle at the initial presentation: anteroposterior view (a) and oblique view (b). An approximately $2-\mathrm{cm}$ osteolytic lesion can be seen in the middle third of the clavicle with slight periosteal reaction.

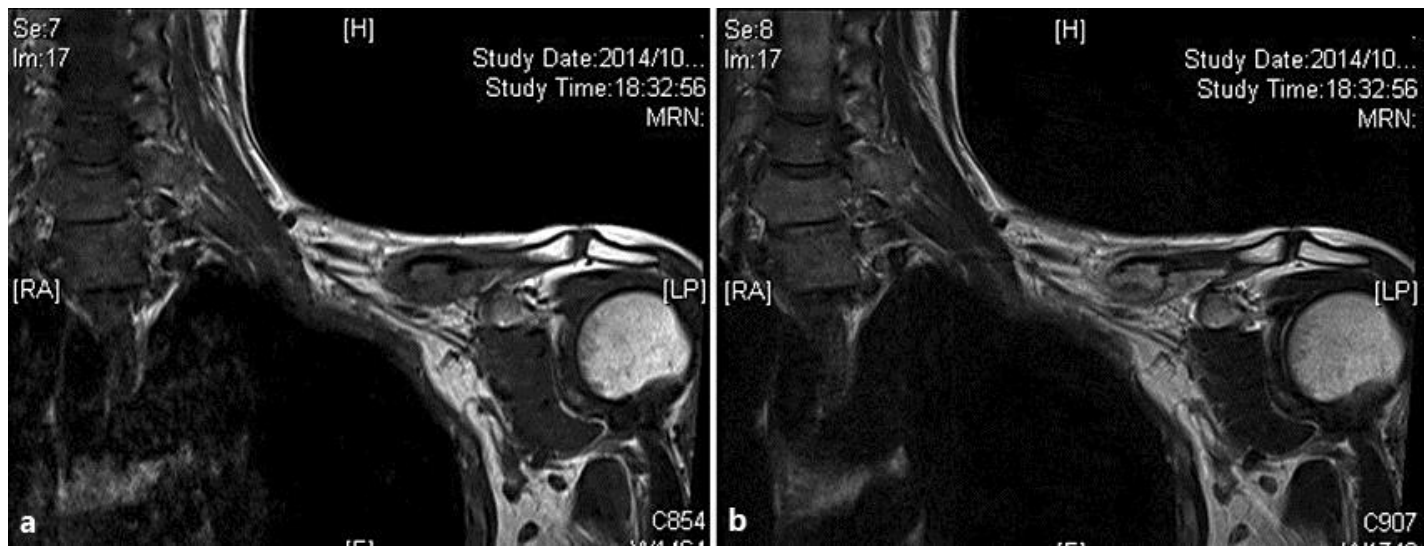

Fig. 2. On MRI, the lesion was depicted as a low-intensity lesion on T1-WI (a) and as a high-intensity lesion on T2-WI (b). An extra-skeletal mass was observed in the inferior part of the clavicle with the lesion extending to the coracoid process. 


\section{Case Reports in Oncology}

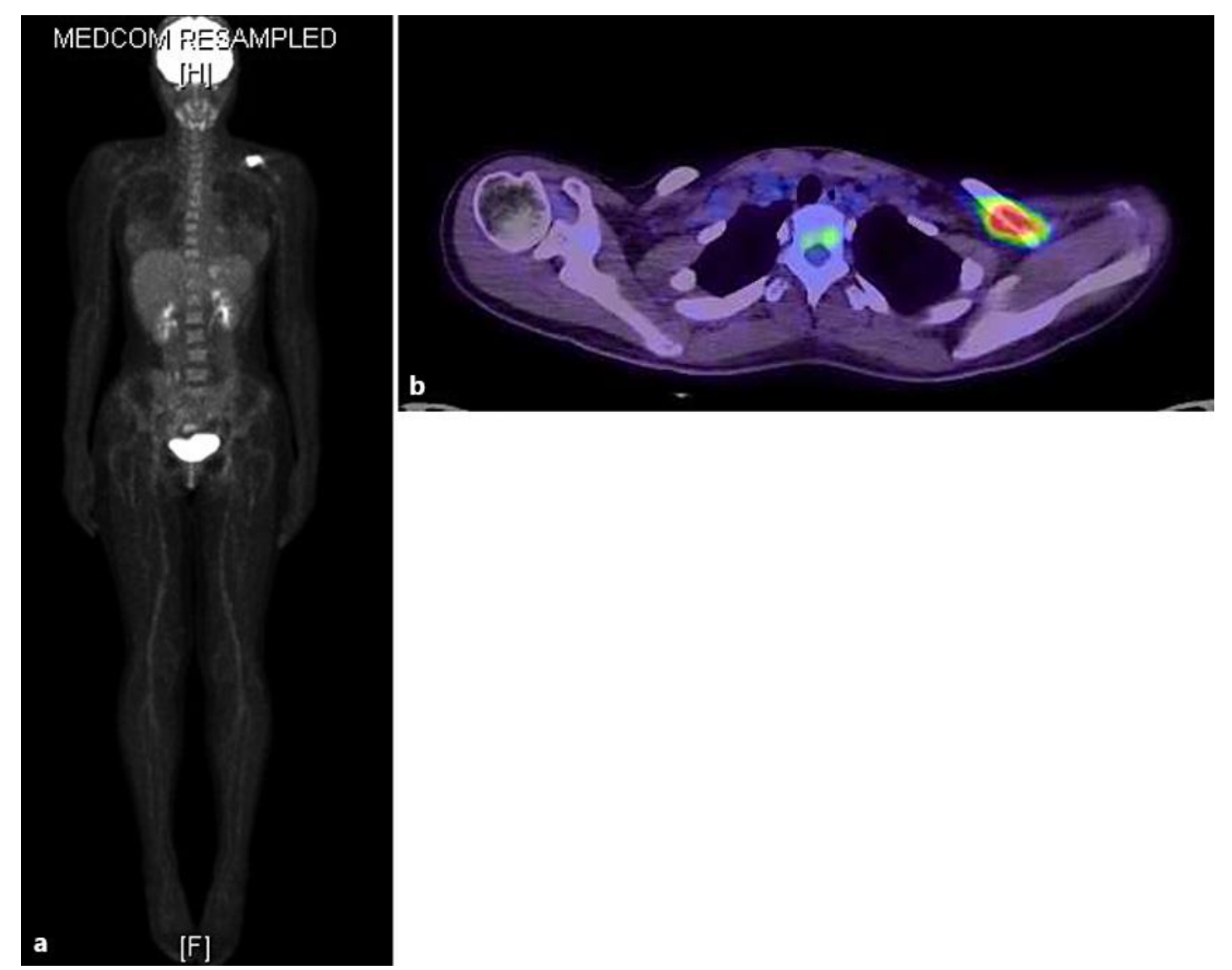

Case Rep Oncol 2015;8:426-431

\begin{tabular}{l|l}
\hline DOI: $10.1159 / 000441415$ & (c 2015 The Author(s). Published by S. Karger AG, Basel
\end{tabular} www.karger.com/cro

Udaka et al.: Langerhans Cell Histiocytosis of the Clavicle in an Adult: A Case Report and Review of the Literature

Fig. 3. On PET-CT, the lesion was solitary (a), with high uptake of FDG (SUVmax: 14.23; b). 


\section{Case Reports in Oncology}

\begin{tabular}{l|l}
\hline Case Rep Oncol 2015;8:426-431 \\
\hline DOI: 10.1159/000441415 & $\begin{array}{l}\text { c } 2015 \text { The Author(s). Published by S. Karger AG, Basel } \\
\text { www.karger.com/cro }\end{array}$ \\
\hline
\end{tabular}

Udaka et al.: Langerhans Cell Histiocytosis of the Clavicle in an Adult: A Case Report and Review of the Literature
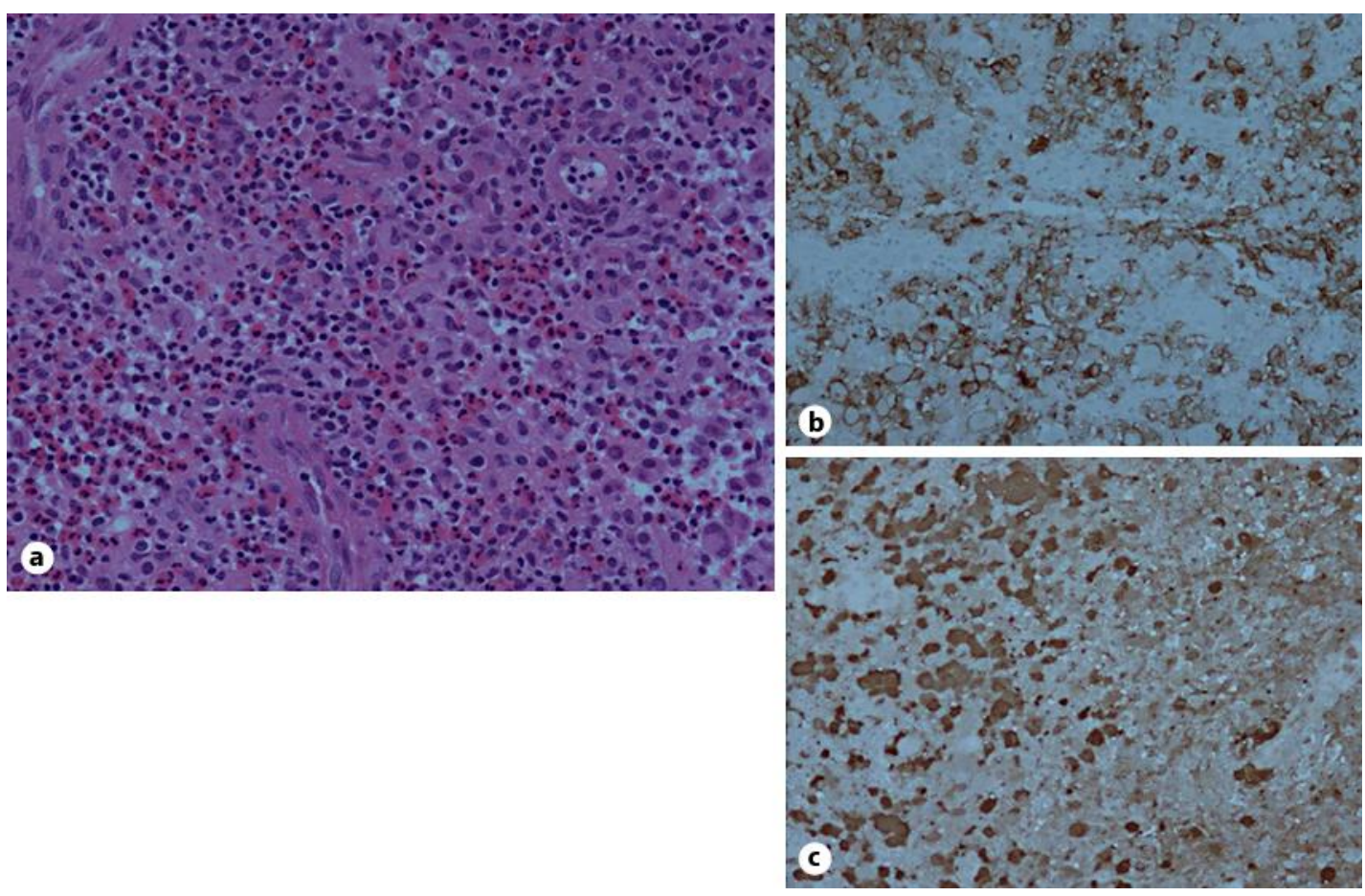

Fig. 4. a Photomicrograph of hematoxylin and eosin staining demonstrating a lesion composed of histiocytic-appearing cells with prominent eosinophils. Immunohistochemical stains were positive for CD1a (b) and S-100 (c), confirming the diagnosis of LCH. 